\title{
HANNIBAL IN GADES: AN INQUIRY INTO THE POETIC TECHNIQUE OF SILIUS ITALICUS IN PUNICA THREE
}

ABSTRACT: Located in Punica Three, the description of Hercules' temple and Hannibal's prophetic dream serve as important instruments of both narrative and poetic techniques, both anticipating events to come and positioning the plot within the intricate nexus of symbols and intertextual allusions that appear to strengthen the Carthaginian's resolve while simultaneously emphasizing the futility of his efforts. At the same time, the two may be studied as examples of sophisticated poetic technique, their reading heavily dependent on reader's knowledge of the semantic framework of Greco-Roman culture.

KEY WORDS: Silius Italicus, Punica, Hannibal in Latin Poetry, ekphrasis, poetic dream

In many ways, Book Three of Silius' Punica stands at what one may rightly call a turning point of the epic. Describing events subsequent to the preliminary conflict i.e. the siege of Saguntum but prior to the invasion of Italy, it contains an account of a crossing, of a spatial movement that effectively transports war from the remote Iberian land to the Virgilian Saturnia regna, and thus to Rome itself. It is in a way emblematic of the book that it depicts events in Gades, the city located at the dividing point between known and unknown waters (i.e. between the Mare Nostrum and the Ocean) and, shortly after, the crossing of the Alps, a mountain range forming another visible division, this time in the form 
of a natural barrier separating Italy from the northern and northwestern lands of Europe. As such, the book could be seen as a tale of movement, travel, and relocation - within its lines, war (and all its horrors so graphically described in Book Two) traverses the natural boundaries and enters the Roman lands. For this reason, if for no other, one would be well advised to pay particular attention to Silian poetics at this point: given the author's general penchant for the intertextual and erudite, it seems logical that this particular learned quality would be of special importance at such an important point of the tale.

As signaled in the title, my principal aim is to inquire into Silius' poetic technique in Punica Three: to achieve this, I shall focus on the opening part of the book, Hannibal's visit to Gaditan temple of Melqart and his subsequent prophetic dream. Certainly, the two respective passages have attracted their share of critical attention and a number of highly interesting and valuable contributions have been made to Silian scholarship: nonetheless, as rightly noted by Iser, it is in the very nature of a literary text that it always lends itself to new interpretation, with each reader paying attention to slightly different aspects of either the plot or its rendering. ${ }^{1}$ This difference in perception or emphasis may lead toward a reevaluation of the poetic devices employed in the text, and, thus, toward a deeper understanding of the authorial choices involved. While my analysis will generally follow the course of Silius' narrative in Punica Three, I shall pay particular attention to the following issues: first, the importance and the employment of snake imagery, then, the issues of exempla and mira, and, finally, the question of ethical virtue as it is related to the latter two. ${ }^{2}$ By focusing on these three I shall endeavor to consider Silius' poetic technique, his compositional intent, or, for that matter, the semasiological complexity of the text.

\section{Cf. Iser 1980.}

2 The importance of the concept of exemplum within the framework of the Silian poem has been recently studied by Tipping (2010). It is to be noted that my inquiry focuses on the possible difference between what happens within the text itself and the reader's response to the exempla in Punica Three. One may also note that M. von Albrecht's study remains a natural reference and starting point for any study of Silius' intertextuality (von Albrecht 1964; particularly 146-166). 


\section{SACRIFICING TO HERCULES}

At the beginning of Punica Three Saguntum lies fallen, its ruin is a grim reminder of the broken fides of past treaties but also, at the same time, a manifest illustration of the fate threatening - within the temporal framework of the work, at least - the city of Rome. As a matter of fact, however, the sad, 'Saguntine' fate will - in actual reality well known to the author and his audience - befall Hannibal's homeland, Carthage. ${ }^{3}$ For the moment, the Punic commander begins his final preparations for the military expedition to Italy: starting with the sacrifice at the temple of Heracles (Melqart), ${ }^{4}$ his actions are consistently aimed at the destruction of his arch-enemy, Rome. Now, Rome, as the poet will repeatedly remind us, enjoys certain connection to Heracles, being linked to the deity through the myth of stolen cattle and Cacus' defeat, as these are described by Virgil. ${ }^{5}$ Given Silius' portrayal of the Saguntine slaughter and its preternatural dimension (cf. the appearance of the Fury), the reader would be likely to conceive of the threat posed by the Carthaginian invasion in much similar terms. The implications of Saguntum appear particularly dire: the striking image of the conquest implicitly links Hannibal's (doomed) expedition to an encroachment of infernal powers unto the land of the living, as an invasion of war madness on a par with that observed, on the one hand, in the poem of Lucan (for the descriptions of slaughter and bloodshed), but also, on the other hand, in Virgil's Aeneid (one thinks of the intervention of chthonic divinities, namely Allecto, in the events of Rutulan war ${ }^{6}$ ).

3 A point duly highlighted by Hardie 1993: 81-82. On the fall of Saguntum cf. also Vessey 1974.

$4 \quad$ On the temple itself, cf. Strabo III 5. Hannibal's visit to the temple in Gades is mentioned by Livy XXI 21: Hannibal cum recensuisset omnium gentium auxilia, Gades profectus Herculi uota exsoluit nouisque se obligat uotis, si cetera prospera euenissent. On the visit as described by Silius cf. Gibson 2005.

As told by Euander in the Aeneid VIII 184-275; the importance of the story for the Punica is discussed (with reference to later books) by Littlewood 2013. One notes that yet additional link exists between Romans and Hercules, as the Fabii (and thus the paradigmatic defender of Rome, Maximus) derive their descent from the mythical hero himself (cf. e.g. Punica II 3: Fabius, Tirynthia proles).

6 Cf. Aeneid VII 323 sq. One notes that in both cases the Fury acts on reality through a female medium (real, i.e. Amata, in Virgil, false in Silius). Meanwhile, the 
At the same time, one is struck by the intrinsic irony of the sacrifice: the ritual celebrating the fall of Saguntum is performed in the temple of the city's founder and protector, Hercules (one will note the strikingly frequent emergence of that particular personage throughout $\mathrm{Pu}$ nica Three ${ }^{7}$ ). The same Hercules is the first hero to have successfully breached the mountainous ridge of the Alps (in this, he precedes Hannibal himself) and, according to Virgil, the archfounder of Rome herself (the slaying of Cacus). Even geography appears to be of possible importance here, as the temple is located in the city of Gades. This puts the sacrifice in a close proximity to yet another place immortalized by the son of Alcmene, namely the Gates of Hercules. In fact, the description of oceanic tides (III 45-60) would of necessity remind the reader of the travels of this great civilizational hero. The situation appears to exacerbate the inherent paradox of Hannibal's situation, his misreading of his own standing within the greater scheme of things and his misperception of fate.

Still, there are further dimensions to the sacrifice: when leaving the temple Hannibal looks at a depiction of Hercules' labors. Aimed at moral instruction (uirtutis imago, III 45) this image appears to leave Hannibal unaffected - it fills his eyes, yet his soul remains untouched by the actual content of the relief. Involved with some attention paid to the slaying of that most famous mythical reptile, the Lernean hydra (III 32-33):

In foribus labor Alcidae: Lernaea recisis

anguibus hydra iacet

The doors displayed the Labours of Hercules. The Hydra of Lerna lay there [...] (Duff 1934: I 115).

Somewhat surprisingly, the mention of the hydra appears first, preceding even the Nemean lion. One should probably keep this fact in mind:

mutual slaughter of the Saguntines, portrayed as it is as both sacrilegious and holy, mirrors the suicidal furor of Vulteius and his soldiers in Lucan's Pharsalia (IV 539-581). On the influence of Virgil's image of Allecto on Flavian epic cf. Hardie 1993: 58-65. On Silius' use of Lucan cf. the general study of Marks (2010) and Brouwers 1982, with particular reference to Punica Three cf. Bruère 1952.

The importance of the Pyrene story as told in Punica Three has been stressed by Vessey 1982 and Keith 2000: 56-57. 
in III 32-33 Hercules triumphs over the reptilian being - this happens in accordance with the will of Jupiter and against that of Hercules' jealous stepmother, which may be taken as a reminder of the situation of Rome, since the city struggles under Juno's jealous wrath. It is important to remember that not so much later Hannibal, the general who had recently destroyed the city once founded by Jupiter's heroic son, appears as a snake. In an oracular dream he appears as a monstrosity laying waste to the Italian land, its mere dimensions sufficient to threaten the order of things. ${ }^{8}$ This repetition of the serpentine image appears fully intentional and meaningful. We are, one thinks, meant to view Hannibal as a monstrosity, a snake sent by Juno to slaughter Rome in its near infancy - in a manner strikingly similar to what happened in the infancy of the son of Alcmene. There is, however, a further complication to the image, as it has appeared earlier, proudly displayed on the shield of Theron, one of Hannibal's more memorable victims, the Saguntine priest of Hercules (II 158-159):

centum angues idem Lernaeaque monstra gerebat, in clipeo et sectis geminam serpentibus hydram.

He bore likewise on his shield a hundred snakes and the monster of Lerna - the hydra that multiplied when the serpents were cut in two (Duff 1934: I 71).

Interestingly, Theron, who achieves the pinnacle of his glory in slaying the African warrior-queen Asbyte, only to die at the hands of Hannibal, appears as something more than a priest: wielding a club and protected by a lion's skin, he projects the image of the god himself. ${ }^{9}$ In killing the voiceless aberration, the African Amazon Asbyte (in a somewhat sacrificial manner including the bashing of her skull), he both repeats the Herculean feat and avenges the death of his fellow priest Mopsus yet, he immediately falls victim to Hannibal's wrath (thus reflecting the powerlessness of Hercules, unable to shield the favoured city from Juno and prefiguring the sacrifice of Sagunt itself). The multilayered image

\footnotetext{
8 The image of Punica III 183-197 is very interesting for its combination of chthonic and celestial elements: the snake appears as large as the celestial constellation of Draco, black, moving with immense noise, etc. For an analysis of the wording compare Spaltenstein 1986: 198-199.
}

$9 \quad$ On the subject cf. Augoustakis 2010: 121-128. 
mirrors the complexity of the poem, reflecting the troubled relationship of the male (Italy) with the female (Africa, Carthage), and the intricacies surrounding the figure of Hannibal, a Carthaginian consumed with (destructive) desire for Rome. ${ }^{10}$

Yet, when we look at the ekphrasis of the temple's door in its entirety, the hydra appears as one of many images of Hercules' unmatched valor - the ten lines mention not less than nine adversaries of Jupiter's great son, the description ending with an image of burning Oeta and the ascension to heaven (III 32-43):

In foribus labor Alcidae: Lernaea recisis anguibus hydra iacet, nexuque elisa leonis ora Cleonaei patulo caelantur hiatu. at Stygius saeuis terrens latratibus umbras ianitor, aeterno tum primum tractus ab antro, uincla indignatur, metuitque Megaera catenas. iuxta Thraces equi pestisque Erymanthia et altos aeripedis ramos superantia cornua cerui. nec leuior uinci Libycae telluris alumnus matre super stratique genus deforme bimembres Centauri frontemque minor nunc amnis Acarnan. inter quae fulget sacratis ignibus Oete, ingentemque animam rapiunt ad sidera flammae. The doors displayed the Labours of Hercules. The Hydra of Lerna lay there with her snakes lopped off, and the strangled head of the Nemean lion was carved with jaws agape. There too the doorkeeper of the Styx, who terrifies the dead by his savage barking, raged at his bonds, when dragged for the first time from his everlasting cavern; and Meagaera stood by, fearing to be fettered too. Nearby were the Thracian horses, and the bane of Erymanthus, and the antlers of the brazen-footed stag that rose above tall trees. And the child of the Libyan land, no easy conquest when he stood upon his mother, lay low, and low lay the ungainly race of Centaurs, half men and half horses, and the river of Acarnania, now robbed of one horn. Amid these figures Oeta shines with sacred 
fires, and the flames carry the hero's soul up to heaven (Duff 1934: I 115-117).

Manifestly, the described artwork aims at portraying the labors and the glory achieved by Jupiter's son in spite of Juno's adversity. It depicts the great civilizing achievement, the repeated slaughter of man-eating monstrosities, inclusive of triumph over the chthonic powers - all the achievements which secured the welfare of the human race in accordance with divine will. Hence, the ornamentation reflects the glory of Heracles, lord of Saguntum, slayer of mythical beasts: accordingly, it ends with his ascent to the heavens, the blaze of Oeta standing for the all-purifying, holy fire of apotheosis. ${ }^{11}$ Yet, at the same time it might be contended that the same fire evokes the memory of another blaze: a similarly 'funeral' pyre that was to erase the identity of the Saguntines, to prepare them for the ultimate, Fury-inspired, death. The two, the city and its founder, are, one may easily claim, inextricably linked, both being consumed by venom and fire. Further, the fire of Oeta, this clear reference to Hercules' apotheosis, constitutes, in an oblique manner, a reminder of the hydra's deadly power: in a much similar manner, Saguntum falls in self-destructive furor instigated (at Juno's request) by Tisiphone, but it is simultaneously immortalized by its valor and steadfastness, a point duly noted in Silius' epitaph for the fallen city (II 696-698):

At uos, sidereae, quas nulla aequauerit aetas,

ite, decus terrarum, animae, uenerabile uulgus,

Elysium et castas sedes decorate piorum.

But you, ye star-like souls, whom no succeeding age shall ever matchgo, glory of the earth, a worshipful company, and adorn Elysium, and the pure abodes of therighteous (Duff 1934: I 111).

Interestingly, the glory of Saguntines' death stands in vivid contrast with the actual fate of Hannibal himself, a point briefly mentioned at the close of Punica Two. Similar to Hercules, the commander will die by poison, but the poison will be self-administered, consumed in fear,

\footnotetext{
11 On the importance of Hercules, the divinized son of Jupiter, within the overall framework of the Punica cf. Asso 2003, 2010.
} 
while its final effect will be vastly different from that of both hydra's venom (as exemplified by Hercules' choice of death) and of the Fury invasion, for he will descend to the darkness of the Underworld deformed, a shadow of his former self (II 704-707):

saepe Saguntinis somnos exterritus umbris

optabit cecidisse manu, ferroque negato

inuictus quondam Stygias bellator ad undas

deformata feret liuenti membra ueneno.

Often, startled in his sleep by the ghosts of Saguntum, he shall wish that he had fallen by his own hand: but the steel will be denied him, and the warrior once invincible in earlier years shall carry down to the waters of Styx a body disfigured and blackened by poison (Duff 1934: I 111).

The image of a body consumed by fire as the soul ascends (or, in Hannibal's case, descends) into its otherworldly abode appears to hold a particular significance in the eyes of Silius: one notices its prominence after the battle of Cannae, as Hannibal honors the fallen Aemilius Paullus:

'I, decus Ausoniae, quo fas est ire superbas

uirtute et factis animas. tibi gloria leto

iam parta insigni. nostros Fortuna labores

uersat adhuc casusque iubet nescire futuros.'

haec Libys, atque repens crepitantibus undique flammis

aetherias anima exultans euasit in auras (X 572-577).

"Go, pride of Italy! Go whither spirits may go that exult in brave deeds! To you fame is secured already by a glorious death, but I must struggle on as Fate drives me, and she hides future events from my knowledge." So Hannibal spoke; and suddenly, mid the crackling of the flames all round, the spirit of Paulus sprang forth and rose triumphant to the sky (Duff 1934: II 91-93).

It seems significant that time after time the actions undertaken by the Carthaginian result (at least for his adversaries) in liberation of the soul, in fiery obliteration of any mortal identity. This effect appears to mirror the mythic fires of Oeta: the Roman (or Saguntine) dead appear - much 
in keeping with the Stoic dogmas - to be cleansed by the fire, to be liberated and hence transformed into a higher form. By contrast, the deformed soul of Hannibal is fated to slink off to the nether realm tainted, 'blackened' by poison (destruction by uenenum as opposite to the cleansing action of fire). One notices that standing by the funeral pyre of the great Aemilius Hannibal wavers, hinting at the uncertainty surrounding his future; ${ }^{12}$ moreover, he invokes the name of Fortuna, that capricious, changeable goddess which wreaks havoc in the affairs of men: in fact, in his moment of triumph he appears envious of the enemy who is free of the labors and cares of mortal life (tibi gloria leto / iam parta insigni, X 573-574).

To return to Punica Three: within the ekphrastic passage depicting the temple, slight emphasis appears to highlight Hercules' triumph over the powers of Hades. As he chains Cerberus, Megaera cowers in fear (metuitque Megaera catenas, III 37), her manifest perturbation attesting to the power of the hero. ${ }^{13}$ Given the prominent role played by another fury, Tisiphone, in the fall of Saguntum, the emphasis may well be intentional: the readers are possibly meant to be thinking of Hercules the conqueror of the Hadean realm as Hannibal seeks the divinity's favor immediately after hell-power itself has been unleashed onto a Herculean city, i.e. Saguntum. Then, as one considers the imagery portrayed in the passage, Diomedes' implicitly mentioned cruelty (III 38) may also be seen as reflecting some of Hannibal's own characteristics: by now, the reader is well aware that the Carthaginian thirsts for human blood, much as was once the case with the man-eating mares of the Thracian king. ${ }^{14}$ Then, there is Hannibal's reputation for swiftness: it will increase throughout this and succeeding books of the poem, leading to considerable anxiety in Rome. Possibly, something of this swiftness of action is anticipated through the image of the Cerynthian deer (III 39). Meanwhile, Hercules' consistent slaying of various monstrous creatures that threaten human peace and welfare may quite likely be taken to constitute a reminder of Jupiter's greater plan: having read the preceding two chants the reader

\footnotetext{
12 Cf. also Littlewood 2013.

13 Interestingly, Spaltenstein (1986: 182) attributes the emergence of this particular image to Silius' own invention.

14 Compare Punica I 59-60: ...penitusque medullis / sanguinis humani flagrat sitis; on the wording see Spaltenstein 1986: 16.
} 
would be able to recognize Hannibal for what he truly is, i.e. a deluded instrument of Juno's wrath, a man blindly fighting a war with no real possibility of victory, his purpose (though not his actions) at odds with the actual will of the gods. ${ }^{15}$ As rightly (though briefly) highlighted by Harrison, the ornate decorations of the Gades temple only serve to emphasize the irony of his position, hence anticipating the future to come. ${ }^{16}$ Yet, Hannibal himself appears blind to their actual meaning, even when faced with the somewhat explicit image of Jupiter's son defeating the monster of Libya, Antaeus (Libycae telluris alumnus, III 40). Admittedly, he sees valor, and he most certainly notes the reward, but he remains impervious to the more complex nuances intrinsic in the semantics of the image. ${ }^{17}$ He will remain similarly unmoved by the great spectacle of the tides (haec propere spectata duci, III 61): he certainly notices their unusual span, indeed appears astounded as well as enthralled by the spectacle (mira cernit, III 46) yet there seems to be no deeper reflection, except for possibly the very practical realization that the tides are of essence when Imilce's departure is concerned, as witnessed in III 153-154. Manolaraki is quite right in pointing out the limitations and haste so characteristic of Hannibal's gaze as contrasted with the far more encompassing outlook of the internal author. ${ }^{18}$ At the same time, one should remember that for any Stoic (and hence, possibly, for Silius ${ }^{19}$ ) the immensity of the oceanic

\section{Compare Vessey 1982.}

16 Compare Harrison 2010: 285-286. The examples he invokes, however, are different: the Nemean lion (due to Fabius' description of Hannibal as Libycus leo in VII 401) and the more legible Antaeus, Libycae telluris alumnus in which he strongly resembles Hannibal himself. The latter simile is all the more important given the fact that Hannibal will be defeated on his maternal land. Furthermore, one may also consider the very real possibility that the very presence of the Centauri on the temple door may find its ideological counterpart in the savage nations that accompany the Carthaginian commander as described in the later part of Punica Three.

17 In this, his intellection is afflicted by the very same weakness that impeded his understanding of the shield as presented to him in Punica II. On the shield cf. Vessey 1975; Komorowska 2012a.

18 Compare Manolaraki 2010.

19 On Silius' Stoicism compare Matier e.g. 1990. Clearly, some caveats are in order at this point: while Silius' philosophical interests are confirmed by Pliny ( $E p$. III 7) and Epictetus (Disc. III 8, 7), while a long praise of suicide is contained in Punica XI, it would be dangerous to assert with absolute certainty that the poet was a pure Stoic himself or, even allowing the latter, that the poet's philosophical stand would neces- 
tides would in all likelihood manifest the orderly nature of the world and, consequently, the power of Jupiter. ${ }^{20}$ Thus, it is not only the deceitful nature of the tides as manifested in the actual fates of the Hannibalic war and described by Livy (XXVIII 8-31) that may have informed the audience's response - it may also be influenced by an association between the tides and the flow of human affairs (this has hardly gone unnoticed by the critics ${ }^{21}$ ). Yet, there is more: according to the order imposed on changing nature by the laws of Jupiter the tides do actually maintain a certain balance. In other words, they are not only a metaphor for fluidity, for the rise and the ebbing of human fortunes, but also - on a more 'philosophical' level - a persuasive manifestation of the order of things, and thus, of the might (and the will) of the supreme deity. One may think of Seneca's observations concerning the understanding of physical phenomena as endowing one with an insight into divinity: Hannibal has no inkling of the true nature of powers which govern the universe and, hence, no idea of the underlying pattern of events. This, however, is only a momentary manifestation of his general intellectual weakness. After all, his disregard for a physical manifestation of order can be seen as a reflection not only of inferior understanding but also of a major ethical flaw. After all, human ethical awareness reflects our ability to appropriately evaluate the physical world with its phenomenal changes. ${ }^{22}$ Hannibal, in his momentary, simple awe for the immensity of the oceanic

sarily shape his work (excessive biographism). On the other hand, it seems plausible that some Stoic influence would be present in the poem regardless of the author's own philosophical belief, particularly given the importance of Stoic philosophy (most specifically ethics) in the education of Roman upper classes (cf. e.g. MacMullen 1992: 46-94).

20 The notion of sea rebelling against the imposed limits (hence, against universal order) emerges briefly in Spaltenstein 1986: 184. Given the present context, one may also be reminded of the contempt for sea navigation as an instrument of human greed (for both riches and power) as voiced by Seneca the Younger in his Natural Questions $\mathrm{V}$ 18, 13-14. Interestingly, in her own discussion of the passage Manolaraki invokes a passage of another Senecan work, Dial. I 1. 4. The passage emphasizes the difference in the understanding possessed by a scientist and a philosopher with that achieved through a cursory glance and a momentary astonishment of a layman.

$21 \quad$ Compare Vessey 1982.

22 Compare Seneca Natural Questions III proem; on the subject cf. e.g. Komorowska 2012 b. 
tides, fails to appreciate its true implication, thus proving himself unable to draw correct inferences from his physical surroundings, to adjust his purpose to the nature of things, and thus, to live a truly human life. This ethical aspect of his failure to contemplate the vision of nature's might becomes particularly important once we consider its immediate context, namely verses III 45-46:

\author{
Postquam oculos uaria impleuit uirtutis imago, \\ mira dehinc cernit; \\ When Hannibal's eyes were sated with the picture of all that valour, he \\ saw next a marvelous sight (Duff 1934: I 117).
}

In gazing at the gates of Hercules' temple, Hannibal was faced with numerous examples of the true virtus, thus the supreme achievements of humankind: in looking at the ocean, he perceives the mira of nature. ${ }^{23}$ Yet, in spite of being faced with two potential sources of ethical instruction, the Carthaginian commander proves unable to employ the vision in such a manner as to draw correct ethical inferences, or as to form correct judgment concerning his own standing within the wider frame of events. Instead, having already chosen, he is consumed by haste, his mind set on destruction of Rome to such an extent that he proves unable (a point seen by Hannon, II 289-326) to discern the potential threat to his own land or to contemplate the wider context of his own actions. But does he actually choose? Given the particularities of Stoic teachings on pathe one may rightly question his autonomy once we realize that the will to avenge Carthage's alleged wrong (and hence, his anger) has been positively bred into him since early childhood, thus impeding any true cognition. ${ }^{24}$ The prominence of bestial images in the book may thus be

\footnotetext{
23 On the concept of exemplum as being of particular importance in the Silian epic, cf. the study of Tipping (2010).

24 One may think of Graver's insightful comments on the Stoic assumptions concerning the development of a false understanding of pathe (Graver 2007: 149-172). One notes that Punica I 38 portrays Hannibal as a personification of Juno's wrath (a point emphasized by Hardie 1993: 64), which would, at least to some extent, limit, or at least influence, his discernment.
} 
taken as a reflection of that less-than-human status of the Carthaginian commander: ${ }^{25}$ for now, however, let us note that there may be an ethical dimension to the image of the tides.

\section{HANNIBAL'S DREAM}

Let us now turn to the issue of the prophetic dream. The motif itself mirrors an impressive number of similar compositional devices known from the earlier literary tradition, but it also reminds the reader of the 'actual' dream of the Carthaginian commander, a dream well attested in the earlier historical sources. ${ }^{26}$ Seen from a purely literary perspective, the appearance of Mercury seems to facilitate the identification of the immediate hypotext, namely Aeneas' encounter with this divine messenger in Aeneid Four. Then, there is the deceitful nature of the omen that is read into the dream as such (regardless of the latter potential for truth): in this, the device recreates another model, this time the dream of Agamemnon, sent by Jupiter in order to goad the Greek commander in chief into launching an attack against Troy in Iliad Beta. To return to the Aeneas link, however: somewhat startlingly, the dream reminder of the role Hannibal is to fulfill in history comes only after his parting with Imilce, while Aeneas had to be reminded of his own destiny in order to leave the Carthaginian shore (and Elissa). ${ }^{27}$ In other words, in the Punica the oracular dream comes despite the fact that there can be no doubt as to Hannibal's resolve (compare the wording of III 158-159: at Poenus belli curis auertere amorem / apparat). Manifestly, the vision as such serves a purpose quite different from that underscoring the appearance of Mercury in the Virgilian hypotext. The entailed promise of plunder and destruction may be perceived both as a further confirmation of the purely destructive character of Hannibal's mission and, simultaneously,

25 The constant tension between the divine, human and bestial aspects of Hercules is considered as holding particular appeal to the Flavian poets by Hardie (1993: 65-73).

26 On dream as a cultural phenomenon cf. above all: Hermes 1996; de Bustamente 1985; for a comprehensive study of dream in Latin epic cf. Grillone 1967. For the historical sources for Hannibal's dream, cf. Stocks 2014: 13-15.

27 For the importance of Imilce within the framework of Punica Three, cf. Vinchesi 1999 and, more recently, Stocks 2014: 80-102. 
as a reminder of the true nature of things, of the divinely sanctioned fate that demands Hannibal's own destruction. Thus, the implicit link between the Carthaginian commander and the monstrous snake appearing within the dream may be seen as a promise (or an anticipation) of his own failure (both intellectual and military).

As for the possible literary sources of the Hannibal's dream: the relevant tale makes its appearance in very similar circumstances in Livy. ${ }^{28}$ Silius' version appears to follow Livy's account, but not without some significant modifications. Thus, in the Punica, the divine youth is openly identified as Mercury, while no blame can be attached to Hannibal's vision as such (in this the poetic account directly opposes that of Livy, in which the vision results from Hannibal acting contrary to the divine command); further, the initial reservation and trepidation of the commander stem from the actual vision rather than from the appearance of the divinity itself. Additionally, the description starts with Jupiter being eager to test and glorify the Roman virtue and hence deciding to rouse Hannibal with nightmares (III 166-167: segnemque quietem / terret et inmissa rumpit formidine somnos; urged on Hannibal's design by breaking his peaceful rest and sending terrors to disturb his sleep). As a result, Mercury hastens to the commander's side exhorting him to fight and invoking Jupiter's commands (III 179-182):

en age, si quid inest animo par fortibus ausis,

fer gressus agiles mecum et comitare uocantem

(respexisse ueto: monet hoc pater ille deorum):

uictorem ante altae statuam te moenia Romae.

Arise! And if aught in your heartis capable of bold action, then go quickly along with me and accompany my summons (I forbid you to look

28 Liv. XXI 22: Ibi fama est in quiete uisum ab eo iuuenem diuina specie qui se ab Ioue diceret ducem in Italiam Hannibali missum; proinde sequeretur neque usquam a se deflecteret oculos. Pauidum primo, nusquam circumspicientem aut respicientem, secutum; deinde cura ingenii humani cum, quidnam id esset quod respicere uetitus esset, agitaret animo, temperare oculis nequiuisse; tum uidisse post sese serpentem mira magnitudine cum ingenti arborum ac uirgultorum strage ferri ac post insequi cum fragore caeli nimbum. Tum quae moles ea quidue prodigii esset quaerentem, audisse uastitatem Italiae esse; pergeret porro ire nec ultra inquireret sineretque fata in occulto esse. 
back: such is the command of Jupiter) and I will set you victorious before the lofty walls of Rome (Duff 1934: I 127).

It is then that the vision begins as a huge serpent appears slithering throughout the Italian land, destruction following in its wake. The description dwells on the dimensions of the monstrous being to such a degree that it rivals those inhabiting the skies (III 189-197):

ecce iugis rapiens siluas ac robora uasto contorta amplexu tractasque per inuia rupes ater letifero stridebat turbine serpens. quantus non aequas perlustrat flexibus Arctos et geminum lapsu sidus circumligat Anguis, immani tantus fauces diducit hiatu attollensque caput nimbosis montibus aequat. congeminat sonitus rupti uiolentia caeli imbriferamque hiemem permixta grandine torquet.

Behold! a black serpent, sweeping along in its huge embrace woods and forest-trees torn from the hills, and rocks dragged along a pathless track, was hissing with a deadly blast. Huge as the Serpent which moves with its coils round the Great ad the Little Bear and encompasses both constellations in its course, so huge it parts its jaws with cavernous yawn, and raises its crest to the height of rain-swept mountains. And the fury of the bursting heavens redoubled the noise and discharged a storm of rain mixed with hail (Duff 1934: I 127).

In accordance with the original description of the dream as frightening, the imagery employed by the poet aims at inspiring dread; that it will be duly appreciated by the Carthaginian leader is ascertained by Mercury, who prevents him from enjoying the full benefits of slumber: instead, Hannibal is positioned somewhere between the states of sleep and wakefulness. To increase the sense of impending doom, Silius introduces a second description of the snake: this time, however, in contrast with the former which was furnished by the omniscient narrator, the description reflects the vision as it is perceived by Hannibal himself (III 200-202): 
... ardua quae sit,

scitatur, pestis terrasque urgentia membra

quo ferat et quosnam populos deposcat hiatu.

Hannibal asked what this terrible monster was, and whither it was bearing its body which weighted down the earth, and what nations were demanded by its open jaws (Duff 1934: I 127-129).

In Hannibal's account the previously used adjective letifer is transformed into the longer phrase quosnam populos deposcat hiatu, possibly reflecting the bloodthirsty and resolute nature of the commander: the questions that Hannibal asks are concerned first with the beast's nature, and then with its purpose (location/direction, enemy/prey). The divinity hastens with explanations, providing yet another description of the ominous creature, but one which introduces a significant change with respect to the original image (III 203-213):

cui gelidis almae Cyllenes editus antris:

'Bella uides optata tibi. te maxima bella, te strages nemorum, te moto turbida caelo tempestas caedesque uirum magnaeque ruinae

Idaei generis lacrimosaque fata secuntur. quantus per campos populatis montibus actas contorquet siluas squalenti tergore serpens et late umectat terras spumante ueneno, tantus perdomitis decurrens Alpibus atro inuolues bello Italiam tantoque fragore eruta conuulsis prosternes oppida muris.'

The god who was born in the cold caverns of fostering Cyllene made reply: "You see war you have prayed for: mighty wars follow in your train, and falling forests, and fierce storms in an angry sky, and slaughter of men, with mighty destruction and doleful doom to the people of Ida. All this is your doing. As that huge serpent with scaly hide laid waste the mountains and hurled the uprooted forests over the plains and wetted the whole earth with its foaming slaver, so you, as huge, will rush down from the conquered Alps and wrap Italy in a black cloud of war; and with a noise like the serpent's you will shatter the walls of towns and root out cities and dash them to the ground" (Duff 1934: I 129). 
Let us first consider the changes introduced into the description: while in the original account the snake was likened - a simile centered on its immensity - to Anguis, the celestial serpent guarding the cosmic axis, Mercury's explanation emphasizes the celestial link, while at the same time stressing both the dynamics and darkness of the image: having conquered the mountains, the creature fills Italy with crashing (fragor), destruction (eruta oppida, convulsis muris) and darkness (atra). This is hardly the northern Anguis, illuminated by its bright Thuban ( $\alpha$ Dra), functionally the twin star of Polaris, the bright star of the North (it is hardly accidental that winter, hiems is mentioned so close to the name of the constellation). Further, the damage it brings in its wake is expressed in terms of human achievement: having overcome a natural obstacle (the Alps) it wreaks havoc with the most manifest products of human civilization: this is how Mercury explains the physical references of III 196-197. It is perhaps in this context that we should be reminded of the description of the tides: after all, Hannibal misreads the sign in a manner which seems to a degree similar. If earlier he was momentarily astonished by the vastness of the oceanic tides, now he misses the crucial point of the dream: the meteorological phenomena mentioned in III 196-197 are of a passing nature, it is the cosmic order alone that stands unchangeable. Yet, he allows himself not to enquire further, to ignore the 'temporal' limitations of the omen.

Further, Mercury's explanation brings into focus the semantic complexity of the word employed to denote the snake in 201, namely pestis. The English equivalent is pest or scourge, which aptly conveys the notion of snakes being thought of as noxious and hostile. However, there might be more to this: first, such pests are to be exterminated, particularly when invading the dwellings of men, and second, given the link between Hannibal and the snake which lies at the heart of the vision, it makes the commander into an enemy of mankind, thus into a threat to be likewise eliminated. In fact, the more emphasis Mercury puts on the repulsive aspect of the beast, the more dehumanized, more snake-like Hannibal becomes. ${ }^{29}$ Why Hannibal, if the snake is thought to represent war as such? The Carthaginian commander, his individuality eclipsed by his role as the ultor, remains in fact the embodiment of Juno's vengeful 
wrath, the war-bringer: it may thus be of particular importance that Mercury does explicitly say that war follows Hannibal into Italy. Further, within the referential framework of Punica Three Silius has repeatedly implied a similarity between him and the mythical beasts that were defeated by Jupiter's son. The memory of Hercules' great triumphs exacerbates the sense of impending catastrophe, of Hannibal, a dutiful worshipper of the Gaditan Hercules, being in fact the most anti-Herculean of all creatures: indeed, the very word pestis, here denoting the snake, has been employed in the ekphrastic passage with reference to the Erymanthian boar (pestisque Erymanthia, III 38) - this may have been disregarded as accidental, but in view of Silius' skilful interweaving of evocative images which additionally appear to reference and reinforce one another (blaze of fire, arson, snakes, etc.) one may justifiably argue in favor of some underlying purpose governing the repetition.

It may easily be argued that the importance of the omen is further emphasized by a compositional device employed, namely threefold repetition. The original description of the snake is provided by the narratorpersona hence giving it the appearance of a 'factographic', objective account: yet, it is from this account that the reader gains the best sense of the beast, an immense, deadly serpent coiling around the imaginary hills, its head level with the mountains, its arrival heralded by deafening noise (ater letifero stridebat turbine serpens, III 191). In the same account we find the allusion to winter in its most destructive aspect: the affinity between the snake and the storm season, known for its cold and humid nature (imbriferamque hiemem permixta grandine torquet, III 197), results in emphasizing the lethal nature of the animal. A much briefer description is then provided by Hannibal himself in his anxious questioning: this allows the reader a more subjective view through the protagonist's eyes, all the while hinting at a certain lack of autonomy on the part of the hero (who, effectively, needs to have the omen interpreted for him instead of interpreting it himself). Finally, the third one originates with an in-dream character, Mercury: this is an interpretation, and significantly, with its references to squalida terga and spumans venenum ${ }^{30}$ it is

\footnotetext{
30 The two may be taken to mirror ater and imbrifer in the first description, thus continuing with the theme of darkness and lethal moisture. Similarly, fragor may be understood as mirroring the cum grandine of the original portrayal.
} 
an image intended to inspire dread. Clearly, while varying in length and focus, each of the three depictions emphasizes the fright that accompanies the appearance of the (warlike) snake and highlights the danger it poses to the world.

Then, one needs to keep in mind the possible importance of several literary predecessors that might have influenced Silius' rendering of the dream motif: first, of the original, deceitful dream of Agamemnon, which lures the king into the battlefield in accordance with Thetis' wish, ${ }^{31}$ then, the already mentioned scene of Laocoon's death, carefully depicted by Virgil in his Aeneid Two, a fatal omen famously misinterpreted by the Trojans, whose blindness leads to the destruction of the entire city, and, finally, possibly the most 'Roman' of all these references, i.e. Mercury's intervention in Aeneid Four, which serves to end the Carthaginian adventure of Aeneas and his companions.

As for the first possibility, the dream reference is emphasized by the deceit practiced by Juno, who is systematically portrayed as preventing Hannibal from learning the true nature of fate (it is not only the dream that misleads him into believing his own invincibility, but also other signs, including the prophecy of Carthaginian priestess in the oath scene of Book One). Further, it serves to rouse Hannibal much in the manner of the dream sent to Agamemnon the night of the fateful attack, the two commanders being purposefully misled by divinities into thinking their enterprise will meet with success. Meanwhile, should we think of Laocoon, the image would of necessity work to emphasize Hannibal's blindness: like the Trojans watching the death of the priest, he contemplates the sign without ever comprehending its true meaning. On the contrary, in misinterpreting the vision, he - like Virgil's Trojans - contributes to the ultimate ruin of his land. At this point one may also be inclined to look forward, to the narrative of Regulus' African expedition as retold in Punica VI, where yet another serpentine being makes its appearance, only to be slain by the Roman general (at the cost of his later defeat). While Augoustakis has persuasively argued in favor of the Virgilian undertone of the episode, ${ }^{32}$ it seems advisable to consider

31 The Homeric character of this particular allusion is further emphasized by the wording of verse III 168, derived from Ilias II 1 sq.

32 Cf. Augoustakis 2010: 182-187. 
a more self-referential possibility. The image of the Roman general slaying a serpent, attested in Livy, ${ }^{33}$ may be taken as a prefiguration of the Roman victory over another snake-like being, Hannibal (a victory paid in blood at the Trasimene, Cannae, etc.), while Regulus' sacrilegious act can be interpreted, a point also noted by Augoustakis, as analogous to Hannibal's breaching of the natural boundary formed by the Alps.

Still, it is highly probable that the two already mentioned hypotexts are to be seen and understood through the filter of the third, namely $A e$ neid IV: it is the latter that provides the decisive reference framework for the other two, and it is only in reading those as superimposed on the Aeneas-Mercury scene that we are allowed to glimpse the possible intent of the author. As Hannibal is instructed by Mercury (much in keeping with the Livian paradigm), he becomes an analogon of the one whose visit in Carthage began the feud, Aeneas. Like that particular hero, he is urged onwards by the divine messenger.

\section{CONCLUSIONS}

In the above, I strove to illustrate some of the techniques employed in Silius' portrayal of Hannibal as it appears in the opening of Punica Three as well as their importance for the overall semantics of the text. Through his skillful employment of intertextual allusions, mythical imagery and historical references, the poet construes an image of the doomed warrior in a manner which reflects the latter's place within the frame of things while simultaneously undermining his every action, and, effectively, his very autonomy. Then, in exploiting the Heracles' myth and making Hannibal into a sort of non-Heracles: he is a creature of Juno, thus the war-bringer and destroyer, while Heracles, the great son of Jupiter, spent his life making the world into a safer place to live. That he actually fulfils the will of Jupiter is only incidental: his intention, after all, is contrary to the established fate (even though, as we know, he follows its course as it was decreed long ago). Furthermore, the prominence of the Herculean myth reflects on Hannibal in yet another manner: being a creature of Juno, he becomes directly opposed to the hero he worships,

33 The account survives in the Periocha XVIII, and Valerius Maximus I 8 ext. 19. 
assuming the characteristics more in line with Eurystheus or, likewise, of the bestial hydra, a monster important for both Hercules' demise and his divinization. This opposition becomes manifest within the illusionary dreamscape, for Hannibal, a figure of war, is likened to a destructive serpent wreaking havoc in Aeneas' promised land: the link with bestial being puts him in direct opposition with monster-slaying Hercules, the founder of civilization.

As for the imagery, the Lernean hydra and the fires of Oeta, both associated with Hercules, scion of Jupiter, the greatest of all human heroes, the Virgilian arch-founder of Rome, and yet, much like Rome itself, a hero who owed the major part of his fame to Juno's implacable hatred, remain possibly the best code-images for the multilayered story, standing, on the one hand, for both the apparent invincibility and endless resourcefulness of Hannibal as well as for his hubristic, yet divinely inspired ambition, and on the other hand, for Rome's capability of rebirth, strength, and glorified, eternal survival.

\section{REFERENCES}

von Albrecht M., 1964, Silius Italicus. Freiheit und Gebundenheit römischer Epik, Amsterdam.

Asso P., 2003, 'Human Divinity: Hercules in the Punica', Vichiana 5, pp. 229-249. Asso P., 2010, 'Hercules as a Paradigm of Roman Heroism', [in:] Brill's Companion to Silius Italicus, A. Augoustakis (ed.), Leiden-Boston, pp. 179-192, [on-line:] https://doi.org/10.1163/9789004217119_009.

Augoustakis A., 2010, Motherhood and the Other: Fashioning Female Power in Flavian Epic, Oxford, [on-line:] https://dx.doi.org/10.1093/acprof:oso/ 9780199584413.001.0001.

Augoustakis A. (ed.), 2013, Ritual and Religion in Flavian Epic, Oxford, [on-line:] https://dx.doi.org/10.1093/acprof:oso/9780199 644094.001.0001.

Brouwers J.H., 1982, 'Zur Lucan-Imitation bei Silius Italicus', [in:] Actus. Studies in Honour of H.L.W. Nelson, J. den Boeft, A.H.M. Kessels (eds.), Utrecht, pp. 73-87.

De Bustamente J.M.D., 1985, 'El sueño como motivo genérico y como motivo tradicional en Silio Itálico', Euphrosyne 13, pp. 27-50. 
den Boeft J., Kessels A.H.M. (eds.), 1982, Actus. Studies in Honour of H.L.W. Nelson, Utrecht.

Fucecchi M., 1992, 'Irarum proles. Un Figlio di Annibale nei Punica di Silio Italico', Maia 44, pp. 45-54.

Gibson B.J., 2005, 'Hannibal at Gades. Silius Italicus 3.1-60', Papers of the Langford Latin Seminar 12, pp. 177-195.

Graver M., 2007, Stoicism and Emotion, Chicago.

Grillone A., 1967, Il sogno nell'epica latina: tecnica e poesia, Palermo.

Hardie P.R., 1993, The Epic Successors of Virgil: A Study in the Dynamics of the Tradition, Cambridge.

Harrison S., 2010, 'Picturing the Future Again: Proleptic Ekphrasis in Silius' Punica', [in:] Brill's Companion to Silius Italicus, A. Augoustakis (ed.), LeidenBoston, pp. 279-292, [on-line:] https://doi.org/10.1163/9789004217119_013.

Hermes L., 1996, Traum und Traumdeutung in der Antike, Zürich-Düsseldorf.

Hinds S., 1998, Allusion and Intertext. Dynamics of Appropriation in Roman Poetry, Cambridge.

Iser W., 1980, 'Interaction between Text and the Reader', [in:] The Reader in the Text. Essays on Audience and Interpretation, S.R. Suleiman, I. Crosman (eds.), Princeton, pp. 106-119.

Keith A.M., 2000, Engendering Rome: Women in Latin Epic, Cambridge.

Komorowska J., 2012a, 'Eneasz, tarcza Hannibala', Nowy Filomata 16, pp. 31-39.

Komorowska J., 2012b, 'Quid est praecipuum? Status and uses of physics in the Naturales Quaestiones of Seneca the Younger', Symbolae Philologorum Posnaniensium 22, pp. 75-89.

Littlewood R.J., 2013, 'Patterns of Darkness: Chthonic Illusion, Gigantomachy and Sacrificial Ritual in the Punica', Ritual and Religion in Flavian Epic, A. Augoustakis (ed.), Oxford, pp. 199-215, [on-line:] https://dx.doi.org/10.1093/ acprof:oso/9780199644094.003.0012.

Manolaraki E., 2010, 'Silius'Natural History: Tides in the Punica', [in:] Brill's Companion to Silius Italicus, A. Augoustakis (ed.), Leiden-Boston, pp. 293-322.

Marein M.-F., Voisin P., Gallego J. (eds.), 2009, Figures de l'étranger autour de la Méditerranée antique, Paris.

Marks R., 2010, 'Silius and Lucan', [in:] Brill's Companion to Silius Italicus, A. Augoustakis (ed.), Leiden-Boston, pp. 127-154.

Matier K.O., 1990, 'Stoic Philosophy in Silius Italicus', Akroterion 35, pp. 69-72.

Ramaglia L., 1952-1953, 'La figura di Giunone nelle Puniche di Silio Italico', Rivista di studi classici 1, pp. 35-43. 
Ronet P., 2009, 'Les comparaisons animales chez Silius Italicus: Hannibal, cet animal barbare', [in:] Figures de l'étranger autour de la Méditerranée antique, M.-F. Marein, P. Voisin, J. Gallego (eds.), Paris, pp. 75-84.

Spaltestein F., 1986, Commentaire des Punica de Silius Italicus (livres 1 à 8), Geneva.

Suleiman S.R., Crosman I. (eds.), 1980, The Reader in the Text. Essays on Audience and Interpretation, Princeton.

Stocks C., 2014, The Roman Hannibal. Remembering the Enemy in Silius Italicus' Punica, Liverpool.

Tipping B., 2010, Exemplary Epic. Silius Italicus' Punica, Oxford, [on-line:] https://dx.doi.org/10.1093/acprof:oso/9780199550111.001.0001.

Vessey D.W.T.C.D., 1974, 'Silius Italicus and the Fall of Saguntum', Classical Philology 69, pp. 28-36, [on-line:] https://doi.org/10.1086/366029.

Vessey D.W.T.C.D., 1975, 'Silius Italicus: The Shield of Hannibal', The American Journal of Philology 96, pp. 391-405, [on-line:] https://dx.doi. org/10.2307/294496.

Vessey D.W.T.C.D., 1982, 'The Dupe of Destiny: Hannibal in Silius, Punica III', Classical Journal 77, pp. 320-335.

Vinchiesi M.A., 1999, 'Imilce e Deidamia, due figure femminili dell epica flavia (e una probabile ripresa da Silio Italico nell' Achilleide di Stazio)', Invigilata lucernis 21, pp. 445-452. 